\title{
Comparison of visual analog pain scores of two different abdominal incisions for Cesarean section: A prospective randomized trial
}

\author{
Sezaryende kullanılan iki farklı abdominal insizyon tekniğinin vizüel analog ağrı skorlarının \\ karşılaştırılması: Prospektif randomize bir çalışma
}

\author{
Sunullah SOYSAL, Mustafa UĞUR, Turgut VAR
}

\begin{abstract}
Objectives: This study compared the Joel-Cohen and Pfannenstiel incisions for cesarean sections by using visual analog scale (VAS) scores and perioperative findings.

Patients and Methods: One hundred pregnant patients were randomly assigned to one of two groups. One group had Joel-Cohen incisions and the other group had the standard Pfannenstiel incision, both by the same surgeon. Intraoperative and postperative findings including the VAS scores of the patients were recorded.

Results: The median total operation time for the Joel-Cohen group was 1500 (1140-3600) seconds and was 1740 (1140-3600) seconds for the Pfannenstiel group. The mean extraction time of the fetus was shorter for the Joel-Cohen group (146.9 \pm 74.4 seconds) when compared to Pfannenstiel group (193.9 \pm 56.5 seconds). Postoperative pain assessment by VAS was similar for both groups.

Conclusion: When urgent extraction of the fetus is needed the Joel-Cohen incision should be chosen for cesarean sections. In other cases, the Joel-Cohen incision technique has no advantage over the standard Pfannenstiel incision so far as postoperative pain is concerned
\end{abstract}

Key words: Cesarean techniques, Joel-Cohen incision, Pfannenstiel incision, VAS.

Sunullah Soysal (凶), Mustafa Uğur, Turgut Var

Obstetrics and Gynecology Clinic, Dr. Zekai Tahir Burak Women Health and Education and Research Hospital, Ankara, Turkey

e-mail:drsunullah@yahoo.com

Submitted/Başvuru: 13.07.2013

Accepted/Kabul: 2.09 .2013
ÖZET

Amaç: Bu çalışmada Joel-Cohen insizyon ve Pfannenstiel insizyon kullanılarak yapılmış sezaryen operasyonlarında vizüel analog skala ile ağrı değerlendirilmesinin ve perioperatif bulguların karşılaştırılması amaçlanmıştır.

Hastalar ve Yöntem: Yüz gebe hasta iki gruba randomize edilmiştir. Bir gruba Joel-Cohen insizyon diğer gruba ise standart Pfannenstiel insizyon uygulanmıştır. İntraoperatif bulgular ve vizüel analog skorlama dahil postoperatif bulgular kayıt edilmiştir.

Bulgular: Joel-Cohen insizyon grubunda ortanca toplam ameliyat süresi 1500 (1140-3600) saniye, Pfannenstiel insizyon grubunda benzer olarak ortanca toplam ameliyat süresi 1740 (11403600) saniye olarak bulunmuştur. Ortalama bebek çıkartma süreleri karşılaştırıldığında Joel-Cohen grubunda (146,9 $\pm 74,4$ saniye) Pfannenstiel grubuna (193,9 $\pm 56,5$ saniye) göre bu sürenin daha kısa olduğu bulunmuştur. Postoperatif VAS ağrı değerlendirilmesi her iki grupta benzer bulunmuştur.

Sonuç: Bebeğin acil çıkarılması gereken durumlarda JoelCohen insizyon tercih edilmelidir. Diğer olgularda Joel-Cohen insizyonun Pfannenstiel insizyona postoperatif ağrı açısından üstünlüğü yoktur.

Anahtar kelimeler: Sezaryen teknikleri, Joel-Cohen insizyon, Pfannenstiel insizyon, VAS.

\section{Introduction}

The most widely performed abdominal operation in obstetrics is the cesarean section. [1] The incisions used for cesarean sections can be classified into two groups: midline incisions and transverse incisions. Transverse incisions are preferred because of their cosmetics results, less pain in the postoperative period and wound strength [2]. The most accepted and most used transverse incision is the Pfannenstiel incision. The Joel-Cohen incision which is also a transverse incision was first used in 1945 for abdominal hysterectomy operations. This technique is supposed to respect anatomical structures more closely, produce less intraoperative blood loss, less postoperative pain and lower febrile morbidity 
$[3,6]$. These advantages of the Joel-Cohen incision have led to this technique being widely used in obstetrics.

Since a sub-aponeurotic dissection of the rectus sheath is not used in the Joel-Cohen incision, it is theorically supposed to cause less pain in the postoperative period. For this reason the present study was conducted to compare the pain levels of patients after a standard Pfannenstiel incision and a JoelCohen incision.

\section{Patients and Methods}

This study was conducted between November, 2009 and June, 2010 in the Zekai Tahir Burak Women's Health and Education and Research Hospital. To be eligible for participation, patients had to have a singleton pregnancy, an indication for cesarean delivery, and be older than 18 years. Patients were excluded if they were at a gestational age lower than 37 weeks, had a previous myomectomy, a previous abdominal incision, a previous cesarean section or if they had maternal diseases requiring long-term medical treatments and diseases complicating pregnancy. The trial was approved by the Medical Ethics Committee of the hospital.

During the study period 100 pregnant women underwent a cesarean section. They were randomised into two groups and 50 of them underwent cesarean section performed by the Joel-Cohen incision and 50 of them by the Pfannenstiel incision. All patients gave written informed consent to participate in the study. For randomization of the subjects a restricted shuffled approach was used. Patients were randomized by a sealed envelope method to undergo either a Pfannenstiel or a Joel-Cohen laparotomy. In the Joel-Cohen group 42 patients underwent an emergency cesarean section and 8 underwent an elective cesarean section. In Pfannenestiel group, 41 patients underwent emergency cesarean section, 9

Table I. Types of Cesarean section and indications for Cesarean Section

\begin{tabular}{lcc}
\hline & $\begin{array}{c}\text { Joel-Cohen } \\
(\mathbf{n}=\mathbf{5 0})\end{array}$ & $\begin{array}{c}\text { Pfannenstiel } \\
(\mathbf{n}=\mathbf{5 0})\end{array}$ \\
\hline Types of Cesarean delivery & $8(16)$ & $9(18)$ \\
Elective & $42(84)$ & $41(82)$ \\
Emergency & & \\
Indications & $17(34)$ & $12(24)$ \\
Cephalopelvic Disproportion & $14(28)$ & $20(40)$ \\
Fetal Distress & $5(10)$ & $4(8)$ \\
Breech Presentation & $5(10)$ & $7(14)$ \\
Large Fetus & $4(8)$ & $2(4)$ \\
Poor Progress in Labor & $1(2)$ & - \\
Cord prolapsus & $1(2)$ & - \\
History of Rectal operation & - & $1(2)$ \\
Transverse Presentation & $2(4)$ & $1(2)$ \\
Lumbar Disc Herniation & $1(2)$ & - \\
Vaginismus & - & $3(6)$ \\
Extremity Presentation & &
\end{tabular}

Values are given as numbers (percentage). underwent an elective cesarean section. The indications for cesarean sections are shown in Table I. A midwife opened the envelopes immmediately before the incision of the skin was made and all the cesarean sections were performed by the same surgeon under general anesthesia.

In the Pfannenstiel technique, the skin incision was placed about $2 \mathrm{~cm}$ above the symphysis with the mid-portion of the incision lying within the shaved area of the pubic hairs. The Joel-Cohen technique included a straight transverse incision through the skin only, $3 \mathrm{~cm}$ below the level of the anterior superior iliac spines (higher than the level of the Pfannenstiel incision). The subcutaneous tissues were opened only in the middle $3 \mathrm{~cm}$. The fascia was incised transversely in the midline then extended laterally with the blunt finger. Finger dissection was used to separate the rectus muscles vertically and laterally and open the peritoneum. All the layers of the abdominal wall were stretched manually to the extent of the skin incision. The bladder was reflected inferiorly. The myometrium was incised transversely in the midline but not to breach the amniotic sac. The myometrium was opened and the opening extended laterally by finger dissection $[3,7]$.

In all patients after the delivery of the fetus, antibiotic prophylaxis with $1 \mathrm{~g}$ of cefazolin sodium (Cefozin Bilim İlaç, Türkiye) and a 15UI of oxytocin intravenous infusion were given immediately after the umbilical cord was clamped. The placenta was separated spontaneously, the uterus was exteriorized and the uterine incisions were closed with a re-absorbable suture material (1-0 Polyglactin 910; Vicryl, Ethicon Ltd, Somerville, New Jersey) using a continuous single-layer locking technique. Additional stitches were positioned on the uterine incision when hemostasis was not satisfactorily achieved with diathermy. The visceral peritoneum was closed, the muscular layers were not re-approximated. Fascial closure was performed with a continuous $1-0$ polyglactin 910 suture (Vicryl, Ethicon Ltd). The skin edges were re-approximated with a 3-0 polyglactin 910 subcuticular suture (Vicryl, Ethicon).

Extraction time was defined as the interval from the skin incision to the clamping of the umbilical cord. The total operative time was defined as the time from skin incision to the end of the skin closure. In postoperative period the patient's hemoglobin levels were recorded at the 6 th hour. For assessment of the pain the (VAS) was used during the 24th hour of the surgery. The VAS was recorded by a midwife who did not otherwise participate in the study. From 0 to 10 points pain scores were chosen by the patients from the VAS charts. A score of 0 refers to no pain. A score of 10 refers to pain as bad as it could possibly be. The same analgesic was given to all patients in the same doses (three times methimazole $1 \mathrm{mg}$ iv/day). All patients were mobilized in the 6th hour after surgery. After the first 24 hours iv treatment was stopped and oral liquid intake was started. After restoration of bowel movements solid food intake was started. On the 10th day of the operation the skin sutures were taken out and the incision sites were examined for infection and other complications. 
The primary outcome of the present study is to evaluate the postoperative pain levels of the patients according to the VAS score system. The secondary outcomes are the total operation time, the fall in hemoglobin concentrations and the extraction time of the fetus.

\section{Statistical Analysis}

The analysis of the data was done with SPSS for Windows 11.5 pack. In order to detect whether the data were normally distrubuted or not, continious variables were analyzed with the Shapiro Wilk test. Descriptive statics for continuous variables were mean \pm standard deviation or median (minimum-maximum) for nominal variables was number of the frequencies and percentage. The significance of the differences of the means were evaluated by Student's $t$ test and for medians the Mann Whitney $U$ test was used. Nominal variables were analyzed with Pearson's Chi-square test. $\mathrm{p}<0.05$ was accepted as statistically significant.

\section{Results}

The demographic findings, body mass index (BMI) and parity status of both groups were not significantly different. The cervical dilatations of the patients before surgery were not different for the two groups. Table II shows the demographic features of the patients.

The median VAS scores of the patients were same in both groups. It was 4 [1-7] for the Joel-Cohen group and 4 [1-8] for the Pfannenstiel group $(\mathrm{p}=0.938)$.

The mean extraction time of the fetus was $146.9 \pm 74.4$ seconds in the Joel-Cohen group and it was 193.9 \pm 56.5 seconds in the Pfannenstiel group $(\mathrm{p}<0.05)$. The median total operation time in the Joel-Cohen group was 1500 (1140-3600) seconds, and in the Pfannenstiel group was 1740 (11403600) seconds $(p=0.064)$. The mean difference between preoperative and postoperative hemoglobin concentration was $1.3 \pm 0.8 \mathrm{gr} / \mathrm{dl}$ in the Joel-Cohen group and $1.0 \pm 0.7 \mathrm{gr} /$ $\mathrm{dl}$ in the Pfannenstiel group ( $\mathrm{p}=0.05$ ). The hospitalization period was the same for both groups. All the patients in the two groups were discharged from hospital on the second day after surgery, except one patient in both groups had 3 days of hospitalization. The median 1st minute APGAR

Table II. Demographic features and cervical dilatation before Cesarean section

\begin{tabular}{lccc}
\hline & $\begin{array}{c}\text { Joel-Cohen } \\
(\mathbf{n}=\mathbf{5 0})\end{array}$ & $\begin{array}{c}\text { Pfannenstiel } \\
(\mathbf{n = 5 0 )}\end{array}$ & $\mathbf{P}$ \\
\hline Age & $26.6 \pm 5.8$ & $25.2 \pm 6.0$ & $0.238 \mathrm{a}$ \\
BMI $(\mathrm{kg} / \mathrm{m} 2)$ & $28.8 \pm 4.5$ & $28.5 \pm 4.4$ & $0.721 \mathrm{a}$ \\
Parity & & & \\
$\quad$ Nulliparity & 37 & 32 & $0.280 \mathrm{~b}$ \\
$\quad$ Multiparity & 13 & 18 & \\
Dilatation $(\mathrm{cm})$ & $4.3 \pm 2.4$ & $3.9 \pm 2.0$ & $0.356 \mathrm{a}$ \\
\hline
\end{tabular}

BMI; body mass index, a Student's t test, b Chi-Square test.
Table III. Intraoperative and postoperative findings of two Groups

\begin{tabular}{lccc}
\hline & $\begin{array}{c}\text { Joel-Cohen } \\
(\mathbf{n}=50)\end{array}$ & $\begin{array}{c}\text { Pfannenstiel } \\
(\mathbf{n}=50)\end{array}$ & P \\
\hline $\begin{array}{l}\text { Mean extraction time of the } \\
\text { fetus (seconds) }\end{array}$ & $146.9 \pm 74.4$ & $193.9 \pm 56.5$ & $<0.05 \mathrm{a}$ \\
Median total operation time & $1500(1140-$ & $1740(1140-$ & $0.064 \mathrm{~b}$ \\
(seconds) & $3600)$ & $3600)$ & \\
Median Hospitalization (days) & $2(2-3)$ & $2(2-3)$ & $1.000 \mathrm{~b}$ \\
Median VAS & $4(1-7)$ & $4(1-8)$ & $0.938 \mathrm{~b}$ \\
Mean fall in Hemoglobin & $1.3 \pm 0.8$ & $1.0 \pm 0.7$ & $0.050 \mathrm{a}$ \\
\hline
\end{tabular}

a Student's t test, b Mann Whitney U test.

score of the newborn for the Joel-Cohen group was 7 (6-8) and for the Pfannenstiel group it was 7 (3-8) and there was no statistically significant difference $(\mathrm{p}=0.074)$. Similarly, there was no difference $(\mathrm{p}=0.78)$ in 5 th minute median APGAR scores between the Joel-Cohen group 10 (9-10) and the Pfannenstiel group 9 (5-10). None of the patients in this study had intraoperative or postoperative complications or needed transfusions of blood or its products. Table III shows the intraoperative and postoperative findings of the two incision groups.

\section{Discussion}

Several studies have claimed that the Joel-Cohen incision at cesarean section is a faster method of delivering the fetus than either the Pfannenstiel incision or the mid-line longitudinal incision. The expected advantages of the Joel-Cohen incision are short fetus extraction times, less postoperative pain and less blood loss [4,8-11]. These observations have not only a clinical impact on the management of women requiring a cesarean section but also have relevant medicolegal implications. Indeed, the admission to a neonatal intensive care unit or, to a lesser extent, the presence of neurodevelopmental abnormalities in an infant delivered by an emergency cesarean section in which a Pfannenstiel incision has been performed could be considered the consequence of an inappropriate surgical procedure.

One of the expected advantages of the Joel-Cohen incision is less intraoperative blood loss. Nabhan et al. compared the Joel-Cohen incision and the Pfannenstiel incision. They reported that decreases in hemoglobin levels in the Joel-Cohen incision group were $0.680 \mathrm{gr} / \mathrm{dl}$ and in the Pfannenstiel group $1.005 \mathrm{gr} / \mathrm{dl}$ [12]. In the present study, the fall in hemoglobin levels were similar in both groups. In the study conducted by Franchi et al. similar hemoglobin level changes were reported for both incision methods. In the Joel-Cohen incision group the hemoglobin count was $1.5 \mathrm{gr} /$ $\mathrm{dl}$ and it was $1.1 \mathrm{gr} / \mathrm{dl}$ in the Pfannenstiel incision group [13]. Also studies conducted by Mathai et al. [14] and Ferrari et al. [15] revealed similar hemoglobin and hemotocrite changes in the Joel-Cohen and the Pfannenstiel incision groups.

The extraction times of the fetus are important, especially in patients when urgent extraction is needed. The mean fetus 
extraction time was found to be shorter for the Joel-Cohen incision in our study $(\mathrm{p}<0.05)$. Franchi et al. reported the mean time elapsed for extraction of the fetus in the JoelCohen group as 3.25 minutes and in the Pfannenstiel group as 4 minutes [13]. Mathai et al also reported similar fetus extraction times; for the Joel-Cohen group 3.7 minutes and the Pfannenstiel group 5.6 minutes [14]. In a similar study conducted by Ferrari et al. the mean time for extraction of the fetus for the Joel-Cohen incision was 4.85 minutes and for the Pfannenstiel incision group 7.11 minutes [15]. Nabhan et al. found the mean time for fetus extraction in the JoelCohen group 4.3 minutes and for the Pfannenstiel incision 7.6 minutes [12]. Since subaponeurotic dissection is not performed in the Joel-Cohen incision less time is spent for extraction of the fetus.

Postoperative pain is an important factor that affects the return of the patients to normal life. In the study conducted by Mathai et al. the postoperative pain of the patients was evaluated by 24 hours as needing a dose of $75 \mathrm{mg}$ pethidine. In the Joel-Cohen incision group the need for $75 \mathrm{mg}$ of pethidine was 2.05 doses and in the Pfannenstiel incision group it was 2.94 doses $(p<0.05)$ [14]. In our study, pain levels of the patients on the day after the operation was evaluated with VAS. No significant pain level differences were found between two incision groups. A study conducted by Ferrari et al. evaluated patients' pain levels with a classification as absent, mild or severe. Similarly, no significant pain level difference was found between the two groups [15].

The perception of the pain is a complex sensation that differs enormously among individuals and it may be affected by age, educational status and emotional status of a patient. AlthoughVAS is supposed to be an objective way of determining levels of pain, an exact level of pain cannot be evaluated.

Since, the extraction time of the fetus may be affected by the method of incision, neonatal outcomes become important. On this basis, we found no difference in APGAR scores of the newborns between two groups and none of the newborns were transfered to neonatal intensive care unit. Ferrari et al. reported no difference in the 5th minute APGAR scores in the Joel-Cohen and the Pfannenstiel incision groups [15]. Similarly, Franchi et al. reported that there was no difference in neonatal intensive care unit transfer numbers between groups [13]. These findings may be attributed to patient selection. In the present study, no high risk pregnancies and preterm labours were included into the study.
In the light of these findings, the Joel-Cohen incision is an alternative technique that can be used in cases of emergency cesarean section, that, however, has no advantage on postoperative pain compared with the standard Pfannenstiel incision technique.

\section{References}

1. Taffel SM, Placek PJ, Moien M, Kosary CL. 1989 U.S. cesarean section rate steadies: VBCA rate rises to nearly one in five. Birth 1991; 18: 73-7. doi: 10.1111/j.1523-536X.1991.tb00063.x

2. Burke JJ II, Gallup DG. Incisions for gynecologic surgery. In: Rock JA, Jones III HW, editors. Te Linde's Operative gynecology Tenth Edition. Philadelphia:Lippincott Williams\& Wilkins, 2008: 246-79.

3. Holmgren G, Sjöholm L, Stark M. The Misgav Ladach method for cesarean section: method description. Acta Obstet Gynecol Scand 1999;78:615-21. doi:10.1080/j.1600-0412.1999.780709.x

4. Stark M, Finkel AR. Comparison between the Joel-Cohen and Pfannenstiel incisions in cesarean section. Eur J Obstet Gynecol Reprod Biol 1994; 53: 121-2.

5. Wallin G, Fall O. Modified Joel-Cohen technique for cesarean delivery. Br J Obstet Gynaecol 1999; 106:221-6. doi: 10.1111/j.14710528.1999.tb08234.x

6. National Collaborating Centre for Women's and Children's Health. Caesarean Section. Clinical Guideline. London: RCOG Press, 2004.

7. Stark M, Chavkin Y, Kupfersztain C, Guedj P, Finkel, AR. Evaluation of combinations of procedures in cesarean section. Int $\mathrm{J}$ Gynecol Obstet 1995; 48: 273-6. doi: 10.1016/0020-7292(94)02306-J

8. Björklund K, Kimaro U, Urassa E, Lindmark G. Introduction of the Misgav Ladach cesarean section at an African tertiary centre: a randomized controlled trial. Br J Obstet Gynecol 2000; 107: 209-16. doi: 10.1111/j.1471-0528.2000.tb11691.x

9. Darj E, Nordström ML. The Misgav Ladach method for cesarean section compared to the Pfannenstiel method. Acta Obstet Gynecol Scand 1999; 78: 37-41. doi:10.1080/j.1600-0412.1999.780109.x

10. Ferrari AG, Frigerio L, Candotti G, et al. Modified Stark procedure for cesarean section. First Italian experience. Int J Gynecol Obstet 1997; 3: 95-102.

11. Franchi M, Ghezzi F, Balestreri D, et al. A randomized clinical trial of two surgical techniques for cesarean section. Am J Perinatol 1998; 15: 589-94. doi: 10.1055/s-2007-994066

12. Nabhan A.F. Long-term outcomes of two different surgical techniques for cesarean Int J Gynecol Obstet 2008;100: 69-75. doi: 10.1016/j. ijgo.2007.07.011

13. Franchi M, Ghezzi F, Raio L, et al. Joel-Cohen or Pfannenstiel incision at cesarean delivery: does itmake a difference? Acta Obstet Gynecol Scand 2002;81:1040-6. doi: 10.1034/j.1600-0412.2002.811108.x

14. Mathai M, Ambersheth S, George A. Comparison of two transverse abdominal incisions for cesarean delivery. Int $\mathrm{J}$ of Gynecol and Obstet 2002; 78: 47-9.

15. Ferrari AG, Frigerio LG, Candotti G, et al. Can Joel-Cohen incision and single layer reconstruction reduce cesarean section morbidity? Int J Gynecol Obstet 2001; 72: 135-43. doi: 10.1016/S00207292(00)00315-5 